\section{Współczesna kreacja wnętrza urbanistycznego za pomocą sztucznej iluminacji, w oparciu o realizacje firmy Arup}

\section{Contemporary Creation of an Urban Interior by Means of Artificial Illumination, Based on Projects by Arup}

\begin{abstract}
Streszczenie
Swatto sztuczne, dające, dzięki nowym technologiom, coraz szersze możliwości wzbogacania i przekształcania obrazu przestrzen nionym efektem współczesnej urbanizacii, stad potrzeba efektywnej kontroli - zarówno kreacyinie, jak i ekonomicznie ie iekologicznie. 作 Przyświeca jej jeden cel: synergia najnowocześniejszej technologii z działaniem pro-środowiskowym. W związku z prześwietleniem miast, skazeniem swielinym i nadmiernym zużyciem energii w godzinach nocnych, Arup zaczął opracowywać taktykę wygaszani przestrzeni miejskie

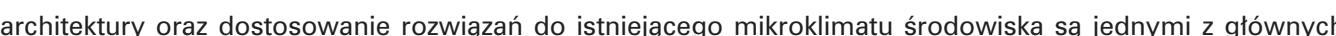
czynników wpływających na powodzenie projektów Arup.

\section{Abstract}

Artificial light, which thanks to new technologies gives us more and more possibilities of enriching and transforming the appearance seems to be, unlike the natural and fire light can be recognised as a certain type of pollution of the natural environment. Light pollution as well as ecological terms.

Arup is one of companies that try to organise and reconcile the currently undertaken measures with the consequences suffered so far. and excessive energy cony of advanced technologies and pro-environmental activity. Due to overillumination in cities, light pollu fon, Respect for the existing architecture and adjustment of the applied solutions to the existing microclimate of the environment consttute ones of the main drivers of success of projects implemented by Arup.

Słowa kluczowe: iluminacja wnętrz urbanistycznych, prześwietlenie miast, wygaszanie przestrzeni miejskiej, skażenie świetlne of cities, turning the light down in the urban space, light pollution

\section{Wprowadzenie}

Istotą reżyserii jest zdolność generowania wrażeń u odbiorcy, oddziaływując (wcześniej) na materię reżyserow dostępna. Zasada 'spójrz uważniej - zobacz więcej' doty czy zarówno oddziałującego na materię twôrcy (architekta-reżysera), jak i odbiorcy-użytkownika wchodzącego w interakcję z rezultatem rezyserskiego oddziaływania na materię. Dotyczy ona wražliwości i umiejętnosci 'czytania' rzeczywistosci "teatru zycia codziennego"1 toczącego się $w$ przestrzeni urbanistyczno-architektonicznej. Zadaniem reżserii przestrzeni w stosunku do miasta jest tworzenie sytuacji przestrzennych ułatwiających Introduction

The essence of directing is the ability to generate certain impressions in a recipient, by means of affecting (berna "Ihe matter avalable to the director. The principle of look more carefully- see more "refers to the creator affecting the matter (architect - director), with the rect of the direcr's action anfering withe effect of the director's actions affecting the the reaty of the "the place in the urban and architectural space.

The task of space directing towards the city is to create spatial situations that foster interaction, stimulate niających niepożądane - budowanie 'scen' sprzyjająszkielet i posługując się elementami tworzywa reżyserskiego, a bazując zarówno na niepowtarzalnym 'genotypie, jak i 'warstwach pamięci' (rozwoju, przekształcen, nawet destrukcji) miasta.

Punktem wyjścia jest 'materia reżyserowi dostepna': jej rozumienie oraz możliwości potencjalnie w niej tkwiące. $Z$ racji dynamicznej natury tej materii- $\mathrm{i}$ dla podkreślenia 'odwieczności' istoty zwiazku człowieka z otoczeniem 'clowy wydaje sie jej opis jako 'żywiotów'. Określenta

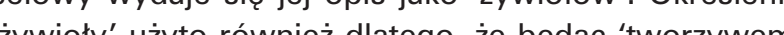

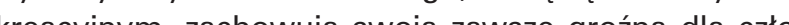
wieka nieza zachóc ‘ż swoja zawsze groźną dla czlo-

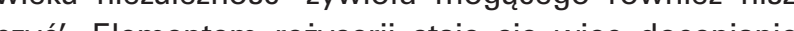
czyc. Elemezlem rezyseril staje sie wiec docenianie,

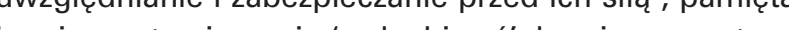
jąc, ze warto się w hie 'wsluchiwa', bowiem w naturze zywioly te, jakkolwiek powodują zniszczenia, bardziej pomagaja życiu, niz szkodzą. Rów zocześnie, okreslenie ,żywioł' podkreśla ich znaczenie asocjacyjne, metaforyczne i dramaturgiczne - dla podejscia reżyserskiego szczególnie istotne, a także pro-ekologiczne ${ }^{2}$.

Materia ta składa się więc z pięciu danych czlowiekowi przez naturę zywiolów oraz z pięciu elementow antropogenicznych. Pierwsze można określić jako 'tworzywo pierwotne: żywioly ziemi, wody, ognia, powietrza i zywiol piaty, zycie - duch i dar istnienia. Ich sens i symbolika zawsze obecne były w działalności ludzkiej a ich kulturowa tradycja zyskuje naturalną kontynuacje w traktowaniu ich jako materii oddziaływania na rzecz zrównoważonego rozwoju. Natomiast drugie: forma (kształtowanie rzeczy kontrolowane myśla), funkcja (pożadane i możliwe działanie, wykorzystanie rzeczy), ruch (dynamika samej rzeczy i dynamika jej odbioru) czas (trwanie rzeczyi jej dynamicznych obrazów), technologia (możliwości techniczne zmaterializowania myśli w rzecz) zostaly wy użycia bezcennego zasobu danego przez naturę.

Żywioł 'ognia' rozumiany jest jako światto i energia. żywiol 'ognia' rozumiany jest jako światlo i energia.

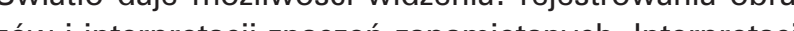
zow i interpretacji znaczen zapamiectanych. Interpretaci w częsci przewidywalnej - obiektywnej - i w częsci su biektywnej, osobistej, bowiem mozg interpretuje to, co widzi oko dzięki posiadanej bazie kulturowej i indywidu alnemu doświadczeniu (skojarzenia, przeżycia). Patrząc na spektakl "teatru życia codziennego" - podobnie jak $w$ teatrze - dzięki tej bazie i wrazliwości jest nam dane zrozumiec znaczenie poszczegolnych kadrow (kulturowa wrazliwosc na symbolicznosc kolorytu natury pozwala na przykład Indianom Navaho widzieć 'skupiska koloru' tam, gdzie my widzimy po prostu góry) i scen zeczywistości, dramatyzuje.

Swiatło sztuczne, dajace, dzięki nowym technologiom coraz szersze możliwości wzbogacania i przekształcania obrazu przestrzeni jednocześnie - w przeciwieństwie do światta naturalnego i ognio-pochodnego - można uzna za swoisty rodzaj skażenia środowiska naturalnego. desired behaviour and hinder the undesired one - to es fostering integration and social expression, by means of creating a directing framework, making use of elements of the director's matte, and basing on the unique genotype, as well as on the memory layers (of the development, transformations, even destruction) of the city.

The starting point is the matter available to the director: its understanding and the opportunities it potentially offers. Due to the dynamic nature of this matter and in order to emphasise the eternal nature of the relation between man and his surroundings, it seems legitimate to describe it as elements. The term "elements" is used also because of the fact that although they are a creative "material, they always maintan their independence of "an element which can also destroy", always menacing for man. Hence what becomes an element of directing is appreciaing, considering, and protecting against heir power, bearing in mind that it is always worth listening intently to them, as in nature these elements, despite their destructive force, provide more help than harm. Simultaneously, the term "element" highlights their associative, metaphoric, and dramaturgical meaning, so important for the director's approach, as well as their pro-eco significance 2 .

Therefore, matter consists of five elements given to man by nature, and of five anthropogenic components. The first ones could be dubbed "the primary material": the elements of earth, water, fire, air, and the fifth element - life - spirit and the gift of existence, Their sense and symbolism have always been present in human activity, and their cultural tradition has been naturally continued in regarding them as a matter of interaction for the benefit of sustainable development. The second group: form (thought-controlled shaping of things), function (desired and possible action, making use of things), motion (dynamics of the thing itself and of its reception), time (duration of things and their dynamic images), technology (technical capacity of materialsinga thought into a thing) have been generated by human intellect, in order to make use of the priceless resources offered by nature.

The element of fire is understood as light and energy. Light offers an opportunity to see: to register images and interpret remembered meanings, in the predictable, objective part, as well as in the subjective, personal part - the brain interprets what the eye sees thanks to our cultural foundations and our individual experience (associations, impressions). Watching the performance of the "everyday life theatre", just like in a real theatre, thanks to these foundations and sensitivity we are offered to understand individua the col the cultural sensitivity to the symbolism of clusters of colours allows the Navajo people to see and scenes of the reality. We are faced with the dramatised reality.

Artificial light, which thanks to new technologies 
Ponieważ 'zanieczyszczenie' świattem wydaje się być nieuniknionym efektem wspó́czesnej urbanizacji. Jest skażeniem niewatpliwym, ale jednocześnie doprawdy malowniczym. Ceniąc malowniczość, należy jednak pamiętać o 'odpowiedniości'. Stąd potrzeba efektywne kontroli - zarówno kreacyjnie, jak i ekonomicznie i ekologicznie - i świadomego powstających konsekwencij stosowania światta sztucznego. Operowanie żywiołem 'ognia' jako świattem, kładzie nacisk na budowanie dynamiki i dramaturgii przestrzeni ze świadomościa jego wieloaspektowego oddziatywania: wystawiam na świato słońca materiały, powierzchnie i krawedzie, błyszczace i matowe, pozwalam powstać tajemniczo gtebokim masom oraz póttonom cieni i ciemności, aby na rzeczach ujawnił się czar światta"

Żywioł 'ognia' jest jednocześnie' dramatycznym symboŻy 'o 'ogn 'jest jednocześnie' dramatycznym symbolem ralnejentio komfortu, czyl, Jeszcze raz, 'odpowiedniosci' przystosowania przestreni wo ostonych warunkach do wymaganych standardów. Ṕojekt energil przestrzeni, definiujący postugiwanie się swiatlem (wykorzstanie naturalnego i wprowadzanie sztucznego) oraz sposób uzycia energi do budowy komfortu biologiczno-funkcjonalnego i psychicznego, należy traktowac jako kreatywne sterowanie - reżyserowanie - zywiołem 'ognia': panowanie nad dy namiką przestrzeni w zmiennym oświetleniu, nad komfortem temperatury $i$ jej stymulacyjnym charakterem, nad mobilnością (wymagającą użycia energii) określonych części składowych reżyserowanej przestrzeni.

\section{Światło sztuczne w przestrzeni zurbanizowanej-} synergia nowoczesnych technologii z działaniem

\section{pro-środowiskowym}

Przed dziedziną nauki, jaką jest urbanistyka, stawiane są wysokie wymagania co do jakosci wnętrz miejskich a okoliczności do spełnienia współczesnych wyzwań sa mocno niekorzystne. Organizmy miejskie poprzez swój szybki rozrost gospodarczy, rozwój technologii, drapieżnie powiększającą się tkankę miejską, podlegają nie do końca kontrolowanym i przemyślanym zmianom.

Firma Arup jest Jedna z firm próbujących uporządkowac i pogodzić obecne działania z dotychczas poniesionym konsekwencjami, a jako priorytet obierając przyszłość doskonalenie jakości środowiska zurbanizowanego ${ }^{4}$

Założył ja wo 1946 roku inżynier-filozof Ove Arup który od samego poczatku wspótpracował z naiwiekszym architektonicznymi twórcami; Renzo Piano Norman Fo ster, Richard Rogers, to tylko niektóre nazwisk z listy. Firma poczatkowo mis ty w bardzo krótkim czase okza sie być no tyly poe, ale

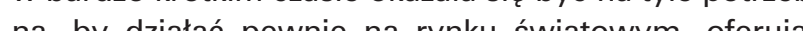
na, by dzlugi parie na rynu swatowym, oferujac

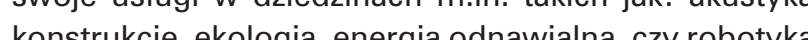
Prźśmica jej jeden cel: synergia najnowoczesnejzej Przyświeca jej jeden cel: synergia najnowoczesniejsze

Arup zajmuje się również sztuką sztucznej iluminacji, gives us more and more possibilities of enriching and transforming the appearance of the space, unlike the natural and fire light can be recognised as a certain type of pollution of the natural environment. Light pollution seems to be an unavoidable effect of the contemporary urbanisation. There is no doub it is a type of pollution, but at the same time quite a picturesque one. Nevertheless, while appreciating picturesqueness, one needs to remember about appropriateness. Hence the need of effective contro - in creative and economic terms alike - and the use of artificial light with the awareness of the consequences. Operating the element of fire as light puts the emphasis on building the dynamics and dramaturgy of space, with the awareness of its multifaceted effect: "I expose glossy and opaque materials, surfaces, and edges to sunlight, I allow the occurrence of mysteriously deep masses and semitone of shadows and darkness, for the charm of light to appear on things"

The element of fire is at the same time a dramatic symbol of the human ability to use the natural energy. The energy which is necessary to achieve comfor and therefore - let me reiterate - the appropriateness of the adjustment of space in specific conditions to the required standards. The project of the "energy of space", defining the use of light (natural and artificial) and the way energy is applied in order to build the biological, functional, and mental comfort, should be regarded as creative controlling - directing - of the element of fire: controlling the dynamics of space in the changing light, controlling the comfort of temperature and its stimulating character, controlling the mobility (requiring the use of energy) of specific components of the directed space.

\section{Artificial Light in Urbanised Space - Synergy of Ad} vanced Technologies and Pro-Environmental Activity Urban planning as a science faces high requirements in terms of the quality of urban interiors, whereas the circumstances in which these requirements need to be satisfied are quite unfavourable. Urban organism due to their rapid economic growth, technologica development, their offensively extending urban tissue are subject to changes which are not fully controlled and deliberate.

Arup is one of companies that try to organise and reconcile the currently undertaken measures with the consequences suffered so far, and their priority is the betterment of the quality of the urbanised environment. ${ }^{4}$

It was established in 1946 by Ove Arup, an engineer and philosopher, which from the very beginning cooperated with the most distinguished architects: Renzo Piano, Norman Foster, Richard Rogers, to mention just a few. Initially, the company was based in London, but soon it turned out to be so needed that it could quite effectively operate on the global market
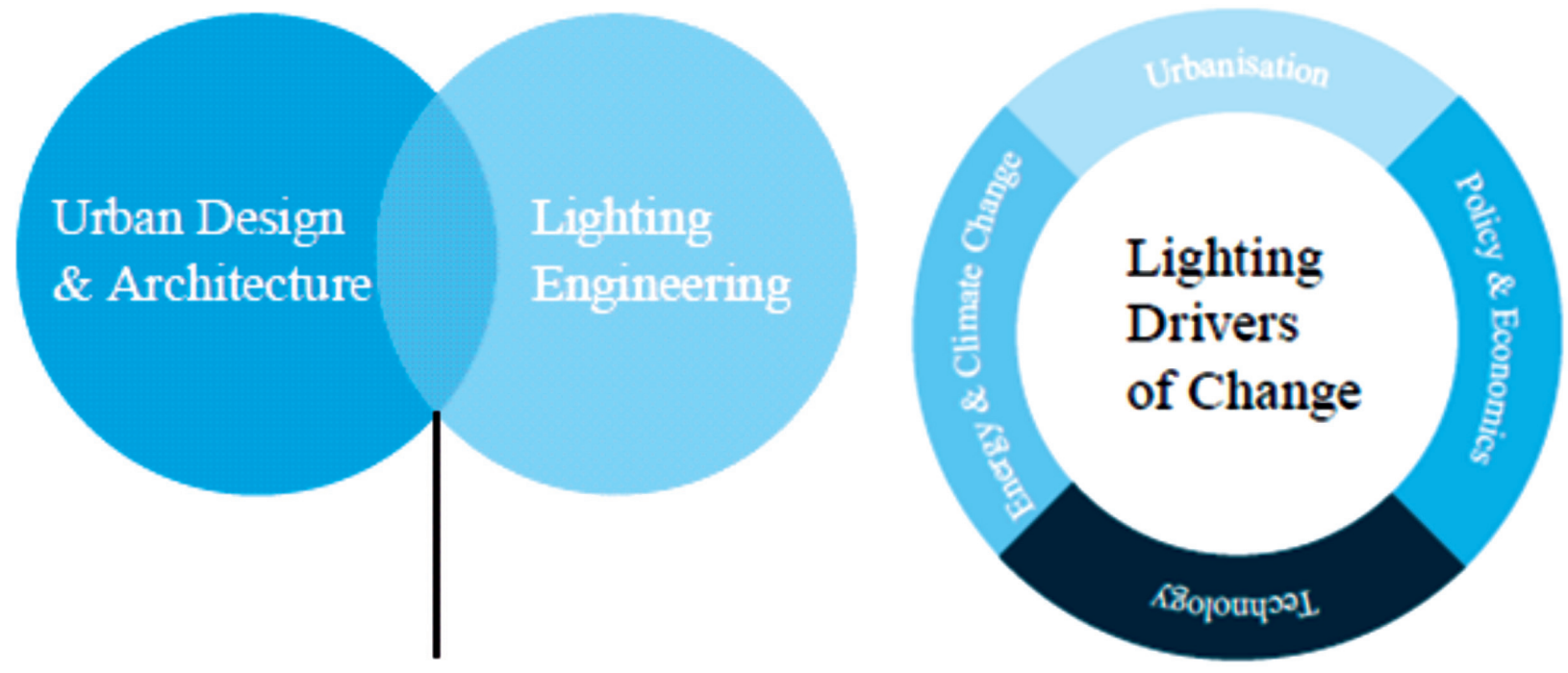

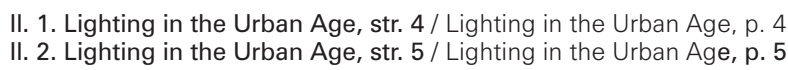

w pełnym tego słowa znaczeniu. Firma współpracuje z artystami, inżynierami oraz architektami, by osiągnąc zamierzony efekt. Kreuje i projektuje m.in. wnętrza urbanistyczne, w synergii z nowościami ze swiata high-tech, tworząc nowatorskie i innowacyjn systemy sztucznej iluminacji oraz korzystajacc z energi słonecznej, wspiera swiatowy ekosystem. Jednakże, $w$ portfolio firmy znajdowały się też takie ingerencje we wnętrze urbanistyczne, które generowały doś dużą ilość lux-ów.

Współcześnie, kierunek sztucznej iluminacji obrał inny tor. W zwiazku z prześwietleniem miast, skażeniem świetlnym i nadmiernym zużyciem energii w godzinach nocnych, Arup zaczął opracowywać taktyke wygaszania przestrzeni miejskiej. 5

Wraz z rosnaca jakościa oprawy świetlnej, w opozyci do jej rozmiaru, planowany jest powrót do wyciemhienia przestrzeni miejskich, w sposćb umo środowisku, powrót do naturalnego cyklu ekosystemu. Na ulicach miast, ruch samochodowy zostanie na sta le sprzeizony z obstugujaca go infrastruktura. Oświetenie uliczne bedzie sie automatycznie aktywown by zapewnić bezpidzźstwo i przygaszać, by uniknąc iepotrze bezpo zużcia energii Tematem do dyskua rón réz ciagi piesze: chodniki akumulujace dyskusi z ruchu przechodniów, wytadowujace ja w iluminace miejsa. Podobny tok myśle dotycy oswiecte ziejsk. Podobny tok myslenia dotyczy oswiellenia skich, mozna je wy rózić za ponoca diod, odb miejskich, można je wyróżnic za pomocą diod, odblasków

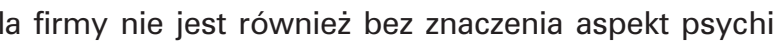
ki ludzkiej. W swoich działaniach biorą pod uwage, jak luminacja wpływa na samopoczucie człowieka i w jak sposob można go jeszcze poprawic. Projektowanie przestrzeni miejskej nie oznacza korzystania jedynie ze sztucznego oświetlenia. Strategia Arup reprezentuje po- tures, ecology, renewable energy, or robotics. It has pro-environmental activity.

Arup is also involved in the art of artificial illumination, in the full sense of the term. The company cooperates with artists, engineers, and architects in order to achieve the planned effect. It creates and designs e.g. urban interiors, in synergy with the latest achievements from the high-tech world, developing ingenious and innovative artificial illumination systems, and by making use of solar energy it supports the global ecosystem. The portfolio of the company, however, includes cases of intervention in urban interiors which generated light intensity of many luxes. Nowadays, artificial illumination has taken another direction. Due to overillumination in cities, light polution, and excessive energy consumption at night, Arup started to develop the tactics aimed to turn down the light in the urban space.

Along with the growing quality of the light setting in ening of urban spaces, so as to enable the environment to recover the natural cycle of the ecosystem. In city streets, car traffic will be permanently coupled with the infrastructure which services it. Street lights will be automatically activated for safety reasons and turned down in order to prevent unnecessary energy consumption. A topic for further discussions are also walking lanes: pavements that accumulate energy coming from pedestrians' movement and allocate it to street illumination. A similar way of thinking refers to cycling lanes - instead of using city lamps, they can be demarcated by means of diodes, reflectors, LEDs in the paving. ${ }^{6}$

The aspect of human mind is also important for the lumination influences man's sense of well-being and but one goal: synergy of advanced technologies and opposition to its size, it is planned to return to darkcompany. In their projects, they consider the ways it- 
gląd, iż bardziej wydajne oraz przemyślane zużycie światta naturalnego, może stworzyc zdrowsze i bezpiecziejsze środowisko do życia codziennego. Fotowoltaika i panele słoneczne współgrają z ideą oszczędzania energii, dbania o innowacyjność miasta oraz jego ekologię.

Współcześnie wnętrze urbanistyczne stało się przestrzenią do pracy, spędzania wolnego czasu, o każdej porz doby. W zwiazku z szybko postepujacymi zmianami wymagań oraz obstugujaca je infrastruktura próbuje sie magan oraz obslugujaca jo infrastruktura, probuje sie źlenia zaprojektowania przestrzeni życiowej róm przyszłość.

Naukowcy z Arup, by sprostać stale rosnacym wyNaukowcy z Arup, by sprostac stale rosnącym wymaganiom, wobec narastajacego lawhowo zuzycia energil, podjeli probe stworzenia efekywnego í modyfikowalnego master-planu, swiethego przestzeni miejskiej. Uwazaja, iz kluczem do sukcesu jest wiedza na temat zalezznosci pomiędzy procesami kreującymi estetyczne whętrze urbanisyczne, a inżynierią swietIną. Integracja tych dwooch ujęc ilum a inacji jest możliwa jeśli zrozumie się właściwie cztery główne czynnik obecnie kształtujące nasze środowisko do życia. Są to: Urbanizacja, Polityka i Ekonomia, Technologia: wiedza na temat Energetyki sprzężona z następującymi Zmianami Klimatycznymi.

Urbanizacja - do roku 2007 prawie 50\% mieszkańców światowej populacji zamieszkiwało obszary miejskie, do roku 2050 ta liczba ma wzrosnać do $75 \% .{ }^{9}$ Współcześnie, ponad $50 \%$ populacji świata zajmuje tereny zurbanizowane. Zgodnie z obserwacjami i badaniami ta tendencja będzie się tylko nasilać. Czynnikami, które maja silny wpływ na zasiedlana przestrzeń miejską sa: zmiany klimatyczne, sytuacja gospodarcza oraz racie wewnatrz społeczeństwa. Kreujac wizje tej przestrzeni, nie możemy nie wzigć ich pod uw wize Procesy zachodzace w metropoliach swa ich pod uw sobie równe. Jedne organizmy miejski roz staja sie w spośb niekontrolorg-

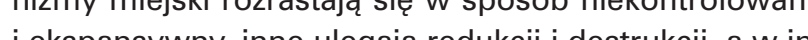
nych poprzez zastosowane regulacje i prawo, przestrzenych poprzez zastosowane regulacje i prawa restrukturyzacji, doskonaleniu'

Jaka jest rola sztucznej iluminacji $w$ tak skomplikowanym i zróżnicowanym działaniu? Na pewno może ona wspierac wzmocnienie tożsamosci miejsca, uwydatnienie jakosci kulturowej oraz opracowalie indywidualne strategii rozwoju przestrzeni i doskonalenia jej oddziatywania.

Polityka i Ekonomia - obowiązujące regulacje międzynarodowe obligują państwa do redukcji emisji dwutlenku węgla. Na pierwszy rzut oka powyższe obostrzenia nie mają bezpośredniego związku ze sztuczną iluminacja. Jednakże, co raz więcej regionalnych dokumentów planistycznych zawiera ten aspekt w swojej tresci. Rola projektanta oświetlenia jest niezwykle interdyscyplinarna. Musi być on świadom problemów dotykających lokalna społeczność, zsynchronizować potrzeby, wymogi i oczekiwania z lokalną polityka, zapewnić estetyczną wartość projektowanej przestrzeni. Świadomość, iż miasta zuży- how it can be further improved. Designing an urban space is not equivalent with making use of artificial light only. Arup's strategy represents the view that more carefully designed and efficient use of natura light can create a healthier and safer environment for the everyday life. Photovoltaics and solar panels harmonise with the concept of saving energy, the care for innovation, and ecology in the city.

Nowadays, a urban interior has become a space for work and pastime at any time of day and night. In order to catch up with quickly progressing changes in the requirements and the infrastructure that services them, it is often tried to satisfy suddenly emerging needs, frequently without considering and designing the living space, also for the future.

So as to be able to meet the constantly growing requirements, in light of the dramatically growin energy consumption, scientists from Arup have atempted to develop an effective and flexible masterplan focused on the illumination of the urban space. They believe that the key to success in this respect is the knowledge of relations between processes creat ing an aesthetic urban interior and light engineering. Integration of these two approaches to illumination is possible if one properly comprehends the four main drivers of our living environment today. These are Urbanisation, Policy and Economics, Technology: knowledge of Energy coupled with the progressing Climate Changes

Urbanisation - in $200750 \%$ of the world's popula tion lived in cities; this will be $75 \%$ in $2050 .{ }^{9}$ Today, over $50 \%$ of the global population inhabits urbanise areas. According to observations and studies, this tendency will intensify. Factors which have a strong impact on the inhabited urban space are: climate changes, economic circumstances, and social relations. We cannot disregard them when creating a vision of this space. Processes that take place in globa metropolises are not equal. Certain urban organism sprawl in an uncontrollable and expansive way, other suffer reduction and destruction, and in some spaces are restructured and improved thanks to the implementation of relevant regulations and laws ${ }^{10}$

What is the role of artificial illumination in such complicated and diversified activities? It can certainly support the strengthening of the identity of the place, emphasising the cultural quality, and developing an individual strategy relating to the development of space and the betterment of its influence.

Policy and Economics - international regulation in force oblige countries to reduce carbon dioxide emissions. At first glance, there is no direct relationship between the restrictions referred to above and artificial illumination. Nevertheless, more and more planning documents cover this aspect. The role of the illumination designer is extremely interdisciplinary. This specialist needs to be aware of issues faced demands, and expectations with the local policy, to wają ponad 2/3 światowej energii i generują około 70\% odpowiedzialności i wartości środowiskową podejmowanych decyzji."

Energetyka i Zmiana Klimatu - w wyniku kończących sie źródeł nieodnawialnych pozyskiwania energii, kryzysu gospodarczego, polityki zarządzania zasobami, miasta musza zminimalizować zarówno koszty instalacji i konserwacji, jak i ogólne zużycie energii. ${ }^{12}$

Według Arup, iluminacja wnetrza urbanistycznego oraz Wed A tra logie postepowania powinny skupić or nastepujących zagadnieniach,

następujajcych zagadnieniach;
- minimalizacja skażenia świetlnego

minimalizacja skazenia swietnego strzennego

zajać się kwestią recyklingu materiałów użytych do produkcji opraw oświetleniowych.

- minimalizacja zużycia energetycznego

- przeanalizować koszty związane z codziennym cyklem funkcjonowania

- przeanalizować relacje sztucznej iluminacji z lokalnym zużyciem energetycznym ${ }^{13}$

Technologia - współczesny postęp technologiczny jes niezwykle dynamiczny i napędza innowacyjność, powszechne zapotrzebowanie na nowoczesne rozwiązania, zmiany $w$ infrastrukturze oraz stylu życia. Wiedza na temat, sprzętu oświetleniowego, zdalnego sterowania oprawą oraz technologii odnawialnej, ma kluczow znaczenie, dostarcza stategiczne argumenty planistom architektom, władzom lokalnym. W związku z szybko postępującymi zmianami w tkance miejskiej, stare modele działania nie są wydajne, m.in. dlatego, iz są skonfrontowane i obsługiwane przez dużo bardziej nowoczesn technologie. ${ }^{14}$

Krokiem milowym dla Arup w zrozumieniu roli sztucznej luminacji, jest zauważenie zmian zachodzących w społeczeństwie, pod jej wpływem.

Technologia winna być wykorzystana w kreatywny sposób, aby zbliżyć ludzi. W krajach mało rozwiniętych oznacza to prawdopodobnie oświecenie wiejskiego sklepu, podczas gdy w Europie interaktywna fasada medialna, która pozwala na interakcje społeczną i ożywia w nocy pozbawiona życia strefę miejską.

Wdrożenie założeń ideowych modyfikacji wnętrz urbanistycznych sztuczną iluminacją w praktykę realizacyjna Firma Arup biorą pod uwaje cztery omówione wyże cztery czynniki zaproponowata taktyke postepowani cztery czynniki zaproponowala taktykę postępowani jich master-plan sztucznej iluminacji wnetrz uac dla nich master-plan sztucznej iluminacji wnętrz urbani-
stycznych.

Sródmieście Msheireb, Doha, Katar

Przestrzeń publicz, Korea Polod lowa

Wszystkie trzy projekty osadzone są w różnych kontekstach, podlegają innym warunkom prawnym, naturalnym secure the aesthetic value of the designed space. The awareness that cities consume over 2.3 of the world's energy and generate ca. $70 \%$ of the global carbon dioxide emissions should only increase the sense of responsibility and the environmental value of the decisions taken."

Energy and Climate Change - As a result of finite resources, the economic crisis, and planning policies, cities must minimise both installation and maintenance costs as well as overall energy use.

According to Arup, illumination of an urban interior and strategies of conduct should focus on the following issues:

- minimise light pollution

- set out environmental zoning standards

-address the recycling of hazardous materials found in light sources

- minimise energy consumption

- consider life cycle costing analyse

- consider the responsivity to light of local ecology Technology - contemporary technological progress is extremely dynamic and it drives innovation, the general demand for advanced solutions, infrastructure and lifestyle changes. The knowledge of lighting equipment, remote control of light sources, and renewable energy is of key importance as it provides planners, architects, and local authorities with strategic arguments. In relation with quickly progressing changes in the urban tissue, old operation models are inefficient, also due to the fact that they are confronted and handled by much more advanced technology. ${ }^{14}$

A true milestone for Arup in the understanding of the role of artificial illumination is noticing the changes happening in the society it causes. Technology can be utilised in creative ways to bring people together. In poorly developed countries perhaps this means i luminating a village shop, while in Europe an interactive media facade which allows social interaction an enlivens a deprived urban zone at night. ${ }^{15}$

Implementation of Ideological Assumptions of Mod fication of Urban Interiors by Means of Artificial Illumination in Practice

Taking into account the four factors discussed above, Arup has proposed the tactics to be followed in three specific locations, by developing masterplans of ar ficial illumination of urban interiors for them.

Downtown of Msheireb, Doha, Qatar New Songdo City, South Korea Public space of Bradford City Park 16

All three projects pose very different urban conditions contexts, local policies and attitudes toward energy optimisation and technology. 17

The discussion of these three examples will allow to assess the effectiveness of the ideological strategy of Arup in practice. 

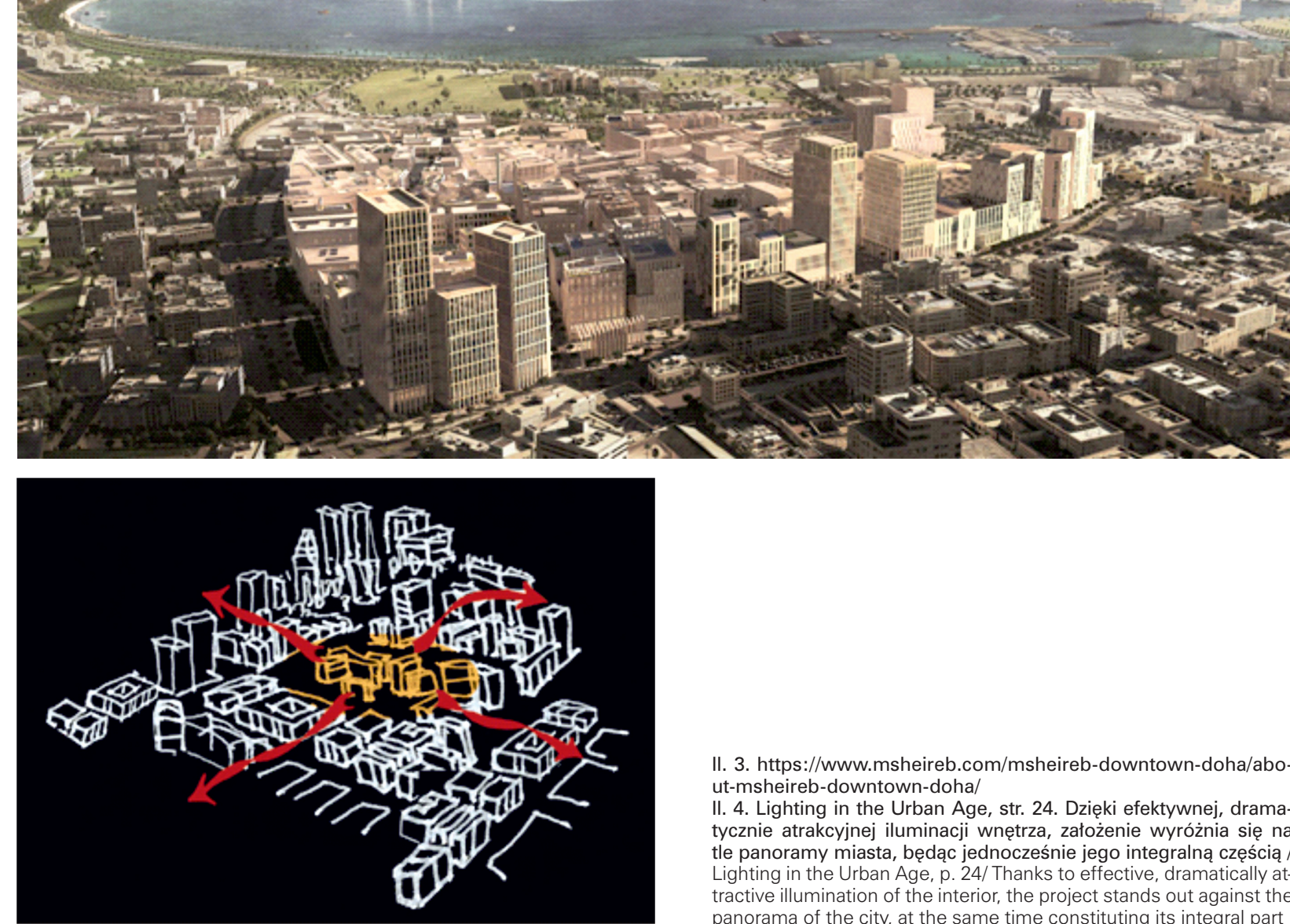

oraz posiadają odmienne podstawy i postawy wobec optymalizacji zuzycia energetycznego.

Omówienie tych trzech przykładów pozwoli na ocene skuteczności strategii ideowej Arup w praktyce.

\section{Śródmieście Msheireb}

Poniższa wizualizacja przedstawia dzielnice Msheireb w kontekście fragmentu miasta Doha wraz z jego linia wybrzeża.

Master-plan 35 hektarowego centrum Dohy jest niewn sztuzzon pod wzgle cen roznorakich zastosowan szluczne pod wzgledem rozinorakich zastosominacia wnetrza pomogla stworzć charakterystyczma zalna $z$ innych punk, kow mista. Poprez in zauma zalna z innych punktow miasta. Poprzez integracje 'zewnętrzem', wprowadza wen energię, która wraca w postaci os b, chcacych partycypowac w sercu Msheireb[ryc.4]. Rola Anup nie ogranicza się tylko do wskazania wytycznych projektowych, firma prowadzi prace na miejscu, projektuje design, rozwiązuje zagadnienia techniczne. Założenia zawarte w głównym planie oswietlenia (Masterplan Development Standards. MDS] to wskazówki dotyczące charakteru rozwoju prze strzeni miejskiej po zapadnięciu zmroku, obejmujące różne elementy infrastruktury, od oświetlenia ulicznego, po sposób informowania i jej oznakowania. Jako, że obszar znajduje się w centrum miasta, jednym z głównych zadań było uszanowanie istniejącego kontekstu i integracja nowej tkanki z tą już istniejąca. ${ }^{18}$ Nie można było nie wziąć pod uwagę kilku czynników kształtujacych atmosferę miejsca: silnych korzeni kulturowych,
II. 3. https://wwww.msheireb.com/msheireb-downtown-doha/about-msheireb-downtown-doha/
II. 4.Lighting in the Urban Age, str. 24. Dieieki efektywnej, drama
tycznie atrakcyjnej iluminacji wnętrza, założenie wyrózinia się na tle panoramy miasta, bẹdac jednocześnie jego integralną czéscia /
Lighting in the Urban Age, p. $24 /$ Thanks to effective, dramatically at tractive illuminination of the interior, the project stands out agaicilyst the
panorama of the city, at the same time constituting its integral part

Downtown of Msheireb

The visualisation provided below presents the distric of Msheireb in the context of a part of the city of Doha along with its coast line.

The masterplan of the 35 -ha inner city of Doha is extremely complex in terms of various applications of artificial illumination, due to the diversity of needs and functions that are to satisfy them. create a characteristic atmosphere of this place, other locations in the city. Through integration with the outside, it introduces energy to it, which of Msheireb [Fig. 4]. The role of Arup is not limited merely to the specification of the designing guidelines; the company performs works on site, develops the design, solves technical issues. The lighting masterplan development standards (MDS) included guidance for the nature of the development after dark, which includes various layers or elements from street lighting to wayfinding and signage, and from general comments to detailed compliance conditions. As the site is located within the centre of Doha, the strategy focused on integrating the proposed development within the exaccount several factors creating the atmosphere of this place: strong cultural and religious roots, geographical location, an actively operating fishing port. Respecting the combination of tradition and ogy, emphasising the multitude of textures, mateArtificial illumination of the urban interior help to which is clearly noticeable when looking from returns as people willing to participate in the heart isting context. ${ }^{18}$ It was impossible not to take into modernity, Arup focused on an innovative technol-

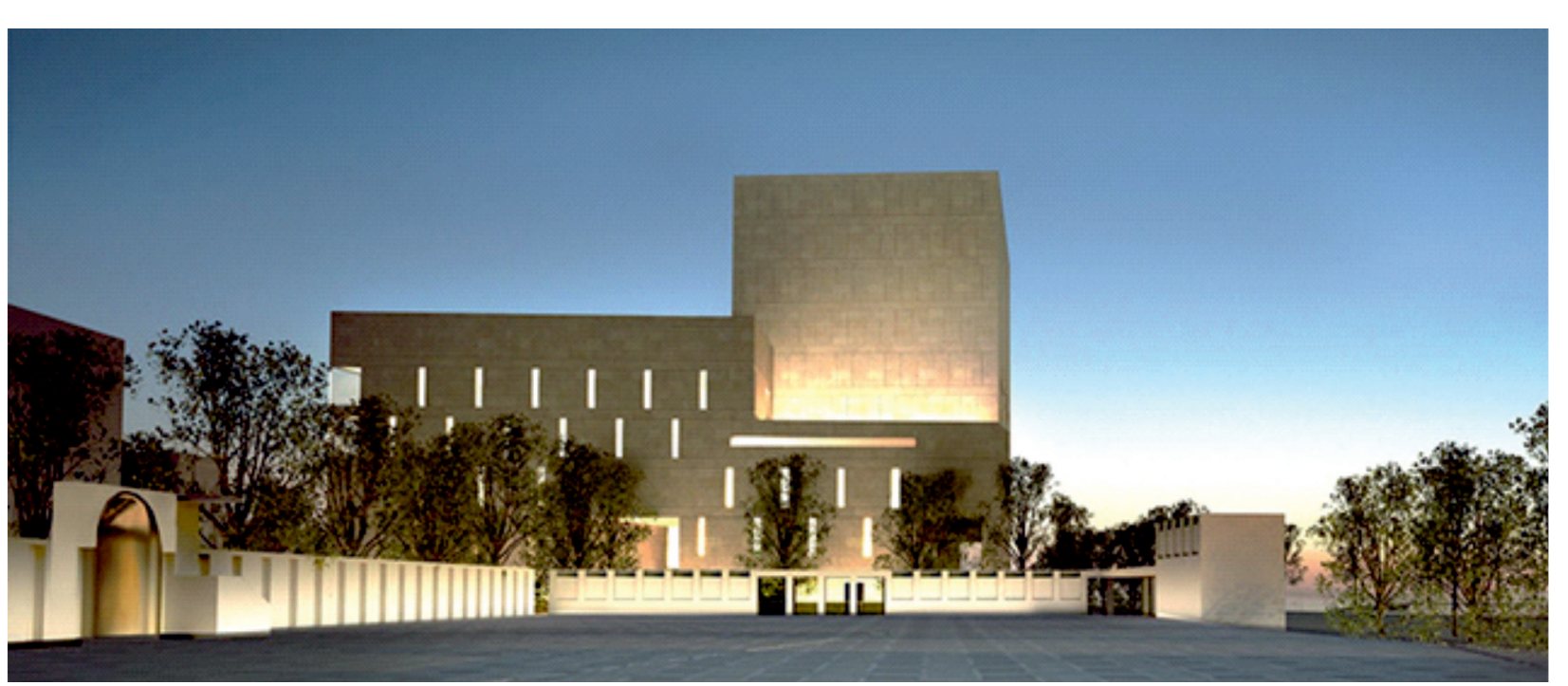

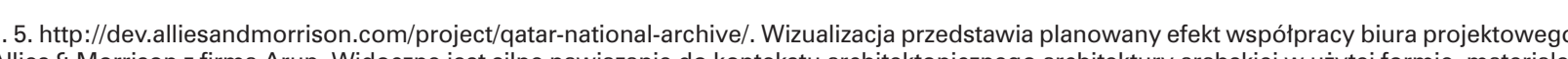

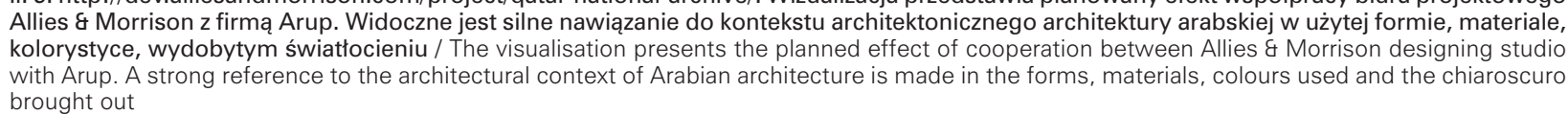

religijnych, położenia geograficznego, aktywnie działającego portu rybackiego. Respektując połączenie tradycji z nowoczesnością, firma Arup skupiła się na nowatorskiej technologii uwydatniającej mnogość tekstu materiałów, światłocień, wydobywając atrakcyjne kierunki perspektywiczne, a jednoczesnie minimalizując poziom skazenia swietlnego i zanieczyszczenia wynikającego ze zużycia energetycznego. [II. 5]

Inżynierowie zastosowali również innowacyjne technologie, dotyczące promenad ciągnących się kilometrami wzdłuż wybrzeża, czy traktów pieszych. Iluminacja wnętrz tworzy wyrazną narrację przestrzeni i tworzy niezwykle zintegrowany całoksztatt. Oprawa świetlną dostosowuje swoją moc do aktualnego zapotrzebowania, tak by wygasić jej intensywność a wykorzystać pełen potencjał tylko na specjalne okazje. Ponad to, całe de koracyjne oświetlenie jest wyłączane, zgodnie z zapisanym planem, w konkretnym momencie, gdy aktywnośc mieszkańców sie zmnieisza. ${ }^{19}$ [1. 7]

Obraz miasta" Kevina Lyncha w którym wyróżnia i punktuje konkretne elementy/atrybuty architektury miejskiej:

rals, the chiaroscuro, bringing out attractive perspective directions, simultaneously minimising the level of light pollution and contamination resulting from energy consumption. [Fig. 5]

Engineers also applied innovative technologies, relating to promenades stretching for miles along the coast, or pedestrian routes. Illumination of interiors creates a clear narration of space and constitutes an extremely integrated whole. The light setting adjusts its intensity to the current demand, turning it down if need be and making full use of it only on specia occasions. Furthermore, the entire decorative illum nation is switched off, in compliance with the masterplan, in a specific moment, when inhabitants' activity decreases. ${ }^{19}$ [Fig. 7]

"The Image of the City" by Kevin Lynch, where he identifies and classifies specific elements / at tributes of unban archilecture: landmarks, edges, nodes, districts, or roads [Fig. 6], was regarded by Arup as tactics, which can be successfully applied

II. 6. Lighting in the Urban Age, str. 19 + własne tlumaczenie / Lighting in the Urban Age, p. 19

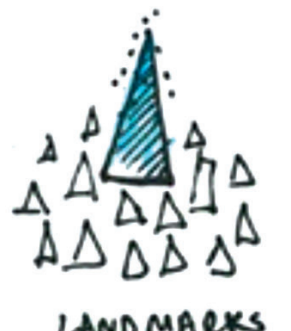

LANDMAEKS

punkty orientacyjne

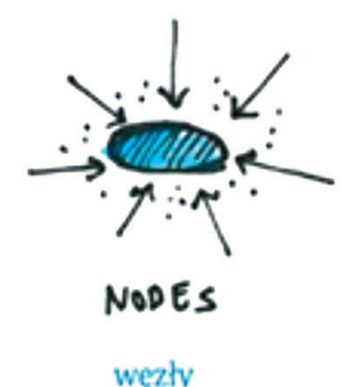

węzly

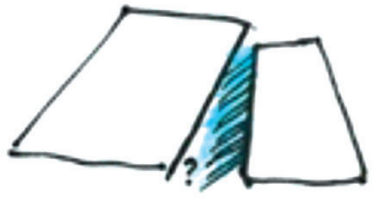

EDEES

krawędzie

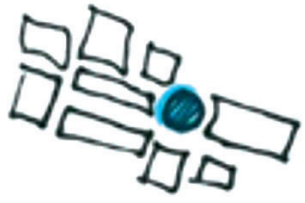

DISTRICTS

obszary 


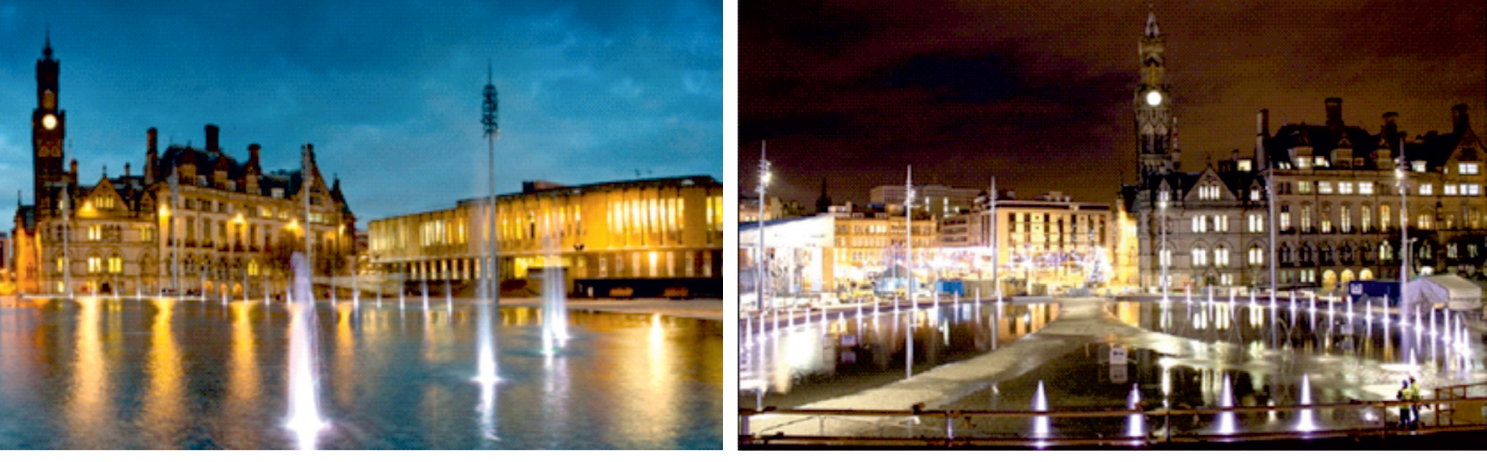

II. 13. https:///premierconstructionnews.com/2012/03/22/bradfords-itty-park-arrives

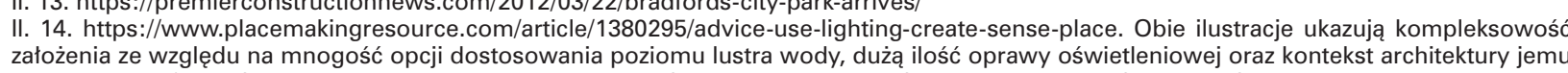

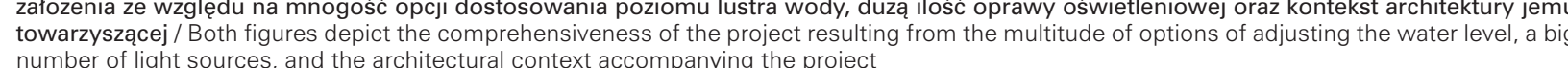

natężenia światła opraw, łącząc szereg funkcji, którym powinna służyć. Nawigacji osób odwiedzających park powinna słuzyc. Nawigacji osób odwiedzających park
i biegaczy wokół parku służy uwydatnienie punktów i biegaczy wokoł parku służy uwydatnienie punktów
strategicznych miejsca, równocześnie szanując istniejącą naturę i jej ekosystem.

W centrum parku miejskiego znajduje się imponujący zbiornik wodny, podkreślony blisko 100 fontannami

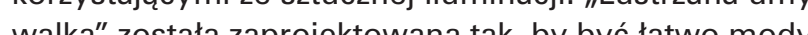
wakca zostalazaprojektowa to by byc latwo modyfikowalną i tworzyc posadzę o róznym ksztalcie i rozmiarze w zależnosci od zapotrzebowania. Firma Arup stanęla przed wyzwaniem zaprojektowania oswietlenia dużej otwartej przestrzeni, unikając efektu jednostajności. Projekt miala charakteryzowac elastycznoś w kreacji atmosfery, jednoczesnie dostosowując się do warunków technicznych zbiornika wodnego i jego po ziomu wody. [II. 12]

Wynikiem podjętych prac na tym terenie, jest iluminacja miejsca wydobywająca się z dziesięciu kolumn o wysokości $17 \mathrm{~m}$, Kórych design zostal opracowany we wspótpracy z artystą Wolfgangiem Buttressem. Projekt obejmuje funkcjonalny sprzęt oświetleniowy, lasery i czujniki interaktywności. Oprawa towarzyszy specjalnym wydarzeniom dedykowanym turystom i mieszkańcom miasta. Całość jest zintegrowana i zarządzana za pomocą centralnego systemu sterowania, tak by automatycznie reagowała na tryb pracy basenu, uwzględniając wysokośc lustra wody. ${ }^{24}$ [II. 13 i 14]

Zintegrowana koncepcja iluminacji ogólnej, warstwy artystycznej, czy uzyskania efektu lustrzanego odbicia basenu, osiaga w swoim szczytowym momencie zużycie poniżej $1 \mathrm{~kW}$ energii. ${ }^{25}$

\section{Podsumowanie}

Sztuczna iluminacja, pomimo stosunkowo krótkiej czasowo ingerencji w przestrzeń życiową człowieka, okazata się być niezwykle istotną w kreacji oraz mocno oddziałującą na wnętrza urbanistyczne i ich modyfikację. Współcześnie poprzez intensywnie rozrastającą się tkankę miejską, drapieżne techniki absorpcji uwagi sztuczna iluminacja zdążyła przytłoczyć obszar zurbanizowany i rozwinąć się w sposób zupełnie niekontrolowany. Szybko postępujacy rozwój technologii iluminacji, nadmierne zużycie lux-ów, doprowadziło do pominięcia aspektów ekologicznych, czego efektem
In the centre of the municipal park there is an impressive water body, highlighted by nearly 100 artificially lluminated fountains. The "mirror pool basin" has pace and create floors of different shapes and sizes, depending on the current needs. Arup faced the chatenge of designing illumination of a large open space, avoiding the effect of uniformity. The design was to be characterised by flexibility in the creation of the be characterised by flexibility in the creation of the
atmosphere, at the same time adjusting to the technial conditions of the water body and its water level. [fig. 12] mination coming from ten 17 -metre tall columns, the design of which has been developed in cooperation with artist Wolfgang Buttress. The project comprises functional lighting equipment, lasers, and interactive sensors. The installation accompanies specia events addressed to tourists and city residents. The entire project is integrated and managed by mean of a central control system to secure its automatic response to the operation mode of the pool, taking the height of the water table into account. ${ }^{24}$ [Fig 13 and 14] The integrated architectural, artist and feature lighting concept for the mirror pool basin achieves a peak consumption of less than $1 \mathrm{kw}$ of energy. ${ }^{25}$

\section{Summary}

Despite its relatively short interference with the living space of man, artificial illumination has turned out to be extremely significant in the creation and strongly influencing urban interiors and modification thereof.

Nowadays, due to the intensely expanding urban tissue and aggressive attention absorbing techniques, artificial illumination has managed to overwhelm urbanised areas and develop in a completely uncontrolled fashion. The quickly progressing development of illumination technologies and the excessive use of luxes has led to disregarding ecological aspects, which results in e.g. light pollution. Another clearly disturbing tendency is the weakening of human sensitivity through the multitude of impressions, which evokes not only an aesthetic anxiety, but also many health issues. The urban tissue is burdened with too many attributes; a certain been designed to provide a flexible multi-function

The result of the works undertaken in this area is illu- jest m.in. skażenie świetlne. Inną, wyrażnie niepokojącą ie ludzkiej wrażliwości, poprzez natłok wrażeń, który prowadzi nie tylko do estetycznego niepokoju, ale i do wielu powikłań zdrowotnych. Tkanka miejska obarczona jest zbyt wielką ilością atrybutów gubi się pewna hierarchia emocji, aspekty dramaturgiczne $z$ reguly nie brane pod uwage, sa przypadkowe lub nieskoordynowane.

Firma Arup i jej działalność jest doskonałym przykładem na minimalizacje negatywnych konsekwencji wynikaja-

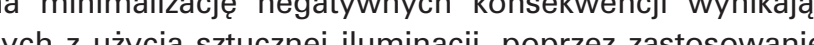
najnowocześniejszej technologii oraz rozwiązań pro-ekologicznych. W jej projektach widoczna jest również niezwykła dbałość o aspekty estetyczne, tak by założenie indywidualne.

Szacun wi zan do istniejącego mikroklinatu śodowiska są jednyprojektów Arup.

PRZYPISY 1. Porb́wnaj: Anna Franta, Reizs seria przestrzeni: o doskonaleniu przestrzeni
publiczzei miasta, Politechnika Krakowska in. Tadeusza Kościuszki, 2004
2 Porównaj: The Hannover Principles. Design for Sustainability, W. Mc Donough Architects, New York 1992

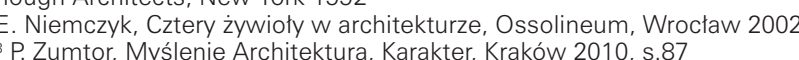
“A Artykut zwizzany jest z problemem badawczym pracy doktorskiej Dominik
Jaszczýnskiej, pod opieka dr hab. inż. arch., prof. PK, Anny Franty- doty

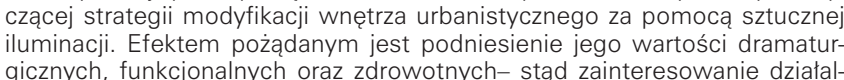
gicznych, funkcjonalnych oraz zdrowotnych- stąd zainteresowanie dziatal-
nościa firmy Arup nościa firmy Arup.
$5 \mathrm{Na}$ podstawie filmu promocyinego Arup. A short introduction, https://
www.youtube.com/watch?v $=0$ MaSGcopNel, 30.08.2018r, godz. 13:00 www.youtube.com/watch?v=OMaSGCPQNel, $30.08 .2018 \mathrm{r}$, godz.
6 Na podstawie fillum promodyinego, Lighting Design In Urban Spa-
ces by Arup - Night Time Is The Right Time, https://www.youtube.com ces by Arup - Night Time II The Right Time: https://Www.youtube.com/
watch?v=dEYVV1YODXfw, 20.08.2018, godz. 15:43 8 Opracowano w W Oparciu o folder informacyiny firmy Arup.
Urban Age, str. 4 Th. whasne fragmentu, Lighting in the Urban Age, str. 5 Urban Age, str. 10 oparciu o folder informacyjny firmy Arup, Lighting in the Opracowano $w$ oparciu o folder informacyiny firmy Arup, Lighting in the ${ }^{2} \mathrm{Tt}$. Whasse e fragmentu, Lighting in the Urban Age, str. 9
${ }^{3} \mathrm{Tt}$. whasne fragmentu, Lighting in the Urban Age, str. 14

${ }_{13}^{13}$ Tt. Whasne fragmentu, Lighting in the Urban Age, str. 14
${ }^{4}$ Oppracowanow w oparciu o folder informacyiny firmy Arup, Lighting in the

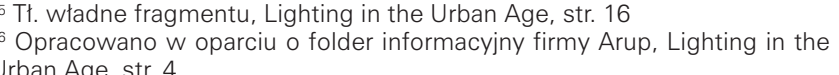

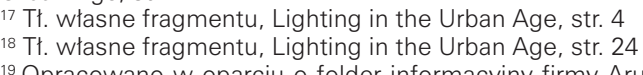

19 Opracowano $w$ oparciu o folder informacyiny firmy Arup, Lighting in the ${ }_{20}^{20}$ Opracowano w oparciu o folder informacyiny firmy Arup, Lighting in the ${ }^{20}$ Opracowano $W$ oparciu o folder informacyjny firmy Arup, Lighting in the
${ }_{21}$ Oprace, str. 18 o $\mathrm{w}$ oparciu o folder informacyjny firmy Arup, Lighting in the

Urban Age, str. 26 oparciu o folder intormacyiny firmy Arup, Lighting in the

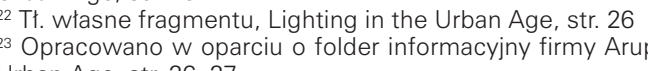

Urban Age, str. 26, 27 . Folder informacyiny firmy Arup. Lighting Opracowano $W$ oparciu o folder informacyiny firmy Arup, Lighting in
the Urban Age, str. 28,29 oraz o https://www.arup.com/projects/city-park-

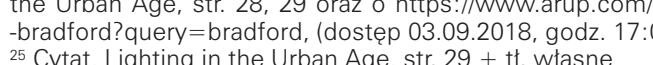

hierarchy of emotions is lost, dramatic aspects are usually disregarded, or else are haphazard or uncoordinated.

Arup and its activity is a perfect example of miniArisation of negative consequences resulting from the use of artificial illumination by means of the most advanced technology and pro-environmental solutions. Its projects testify to the company's unique care for aesthetic aspects, so that each project could be inscribed in the local context and enhance its individual properties.

Respect for the existing architecture and adjustment of the applied solutions to the existing $\mathrm{m}$ croclimate of the environment constitute ones the main drivers of success of projects implemented by Arup.

ENDNOTES

C.: Anna Franta, Reżyseria przestrzeni: o doskonaleniu przestrenin publiczne, mias
ty of Technology, 2004
2. Donough Architects, New York 1992
E. Niemczyk, CZtery żywiofy $w$ architekturze, Ossolineum P. Zumtor, Myślenie Architektura, Karakter, Cracow 2010, p.87

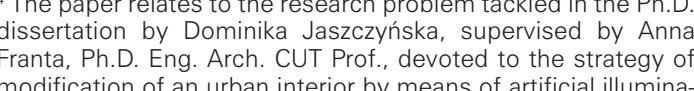
tion. The desired effect is to enhance its dramatic, functional,
and health-related values - hence the interest in the activities of Arup. 5 Based on the promotion video, Arup. A short introduction
https.//www. youtube.com/watch?v $=$ OMqSGCpQNel. https://www. youtu B. Based on the promototion video, ARUP Lighting Futures, https://
kimeo.com/241678746, 10.09.2018, 13:02 hrs Based on the promotion video, Lighting Design In Urban Spa-
ces by Arup - Night Time Is The Right Time htrps be.com/watch?v=dEyV1yODXfw, 20.08.2018, 15:43 hrs in the Urban Age, $p$. 4

9. Lighting in the Urban Age, p. 5
10 Compiled basing on the promotion brochure of Arup, Lighting in the Urban Age, p. 10 ,
'Compiled basing on the promotion brochure of Arup, Lighting In the Urban Age, p. 12
12 Lighting in the Urban Age, p. 9

Compiled basing on the promotion brochure of Arup, Lighting the Urban Age, p. 16
SLighting in the Urban Age, p. 16

16 Compiled basing on the promotion brochure of Arup, Lighting
in the Urban Age. 4.4 . 16 . in the Urban Age, p. 4
7 Lighting in the Uurban Age, p. 4
78 Lighting in the Urban Age, p. 24

Compiled basing on the promotion brochure of Arup. Lighting in the Urban Age, pp. 24,25
20 Compiled basing on the prom 作 22 Lighting in the U. Urban Age, p. 26
${ }^{23}$ Compiled basing on the rom

Compiled basing on the promotion brochure of Arup, Lighting Compiled basing on the promotion brochure of Arup, Lighting in the Urban Age, pp. 28,29 and https://Www. arup.complproje
cts/city-park-bradford? query=bradford, (access on 03.09.2018 $17: 00$ hrs)
25
Lighting in the Urban Age, p. 29 


\section{LITERATURA}

[1] Anna Franta, Reżyseria przestrzeni: o doskonaleniu przestrzeni publicznej miasta, Politechnika Krakowska im. Tadeusza Kościuszki, 2004

[2] Barbara Stec, O świetle we wnettru: relacja miedzy światłem słonecznym a architekturą $w$ aspekcie atmosfery architektury, Oficyna Wydawnicza AFM, 2017

[3] Barbara Stec, Aspekty scenografii w architekturze współczesnej, wzmocnienie oddziaływania formalnego architektury przez wprowadzenie elementów scenograficznych, Politechnika Krakowska im. Tadeusza Kościuszki, 2000

[4] Gernot Böhme, Atmosphäre: Essays zur neuen Ästhetik, Frankfurt, 1995

[5] Lighting in the Urban Age Meaningful design for cities, people \& places, Arup

[6] Night-time design, Pilot installation in Getsemaní Cartagena, Colombia, Arup

[7] Cities alive, Rethinking the shades of night, Arup

[8] LSE Cities Report, October 2014 - December 2016, Arup

[9] The Hannover Principles. Design for Sustainability, W. Mc Donough Architects, New York 1992

[10] E. Niemczyk, Cztery żywioły w architekturze, Ossolineum, Wroctaw 2002

[11] E. Saarinen, the City, Its Growth, Its Decay, its Future, MIT Press, Cambridge Mass., 1965

[12] P. Zumtor, Myślenie Architekturą, Karakter, Kraków 2010, s.87

[13] https://www.arup.com/perspectives/cities-alive-lighting-the-urban-night-time (dostęp: 10.2018)

\section{BIBLIOGRAPHY}

[1] Anna Franta, Reżyseria przestrzeni: o doskonaleniu przestrzeni publicznej miasta, Tadeusz Kościuszko Cracow Universty of Technology, 2004

[2] Barbara Stec, O świetle we wnętrzu : relacja między światłem słonecznym a architekturą $w$ aspekcie atmosfery architektury, AFM Publishing House, 2017

[3] Barbara Stec, Aspekty scenografii w architekturze współczesnej, wzmocnienie oddziaływania formalnego architektury przez wprowadzenie elementów scenograficznych, Tadeusz Kościuszko Cracow Universty of Technology, 2000

[4] Gernot Böhme, Atmosphäre: Essays zur neuen Ästhetik, Frankfurt, 1995

[5] Lighting in the Urban Age Meaningful design for cities, people \& places, Arup

[6] Night-time design, Pilot installation in Getsemaní Cartagena, Colombia, Arup

[7] Cities alive, Rethinking the shades of night, Arup

[8] LSE Cities Report, October 2014 - December 2016, Arup

[9] The Hannover Principles. Design for Sustainability, W. Mc Donough Architects, New York 1992

[10] E. Niemczyk, Cztery żywioły w architekturze, Ossolineum, Wroclaw 2002

[11] E. Saarinen, The City, Its Growth, Its Decay, Its Future, MIT Press, Cambridge Mass., 1965

[12] P. Zumtor, Myślenie Architektura, Karakter, Kraków 2010, p. 87

[13] https://www.arup.com/perspectives/cities-alive-lighting-the-urban-night-time (dostęp: 10.2018) 